\title{
The Pseudomonas chlororaphis PCL1391 Sigma Regulator psra Represses the Production of the Antifungal Metabolite Phenazine-1-Carboxamide
}

\author{
Thomas F. C. Chin-A-Woeng, Daan van den Broek, Ben J. J. Lugtenberg, and Guido V. Bloemberg \\ Leiden University, Institute of Biology, Clusius Laboratory, Wassenaarseweg 64, 2333 AL Leiden, The Netherlands
}

Submitted 13 July 2004. Accepted 29 October 2004.

The rhizobacterium Pseudomonas chlororaphis PCL1391 produces the antifungal metabolite phenazine-1-carboxamide (PCN), which is a crucial trait in its competition with the phytopathogenic fungus Fusarium oxysporum f. sp. radicis-lycopersici in the rhizosphere. The expression of the PCN biosynthetic gene cluster in PCL1391 is population density-dependent and is regulated by the quorum-sensing genes $p h z I$ and $p h z R$ via synthesis of the autoinducer $N$ hexanoyl-L-homoserine lactone $\left(\mathrm{C}_{6}\right.$-HSL). Here, we describe the identification of an additional regulatory gene of $\mathrm{PCN}$ biosynthesis in PCL1391. A mutation in the psrA gene (Pseudomonas sigma regulator), the gene product of which is a member of the TetR/AcrR family of transcriptional regulators, resulted in increased production of autoinducer molecules and PCN. Expression studies showed that inactivation of $p s r A$ resulted in increased expression of the $p h z I$ and $p h z R$ genes and the $p h z$ biosynthetic operon and that introduction of functional copies of $p s r A$ represses the expression of these genes, resulting in reduced production of autoinducer signal and PCN. Surprisingly, inactivation of psrA in the phzI or $p h z R$ quorum-sensing mutants, which do not produce detectable amounts of PCN and autoinducers by themselves, restored PCN biosynthesis. This phenomenon was accompanied by the appearance of compounds with autoinducer activities migrating at the positions of $\mathrm{C}_{4}$-HSL and $\mathrm{C}_{6}$-HSL on $\mathrm{C} 18$ reverse phase-thin-layer chromatography. These observations indicate that PsrA also represses at least one silent, yet unidentified, quorum-sensing system or autoinducer biosynthetic pathway in PCL1391. The expression of psrA declines at the onset of the stationary phase at the same moment at which quorum-sensing (-regulated) genes are activated. In addition, expression studies in a $\mathrm{psr}^{-}$and a multicopy psrA background showed that psrA is autoregulated. Multiple copies of $p s r A$ repress its own expression. Mutation of $\mathrm{gacS}$, encoding the sensor kinase member of a two-component global regulatory system significantly reduced production of autoinducers and PCN. We show a novel link between global regulation and quorum sensing via the PsrA regulator.

Additional keywords: biocontrol, tomato foot and root rot.

Corresponding author: Guido V. Bloemberg; Telephone: +31 71 5275056; Fax: +31 71 5275088; E-mail: bloemberg@ rulbim.leidenuniv.nl
Pseudomonas chlororaphis PCL1391 exhibits biocontrol activity of tomato foot and root rot caused by Fusarium oxysporum Schlechtend.:Fr. f. sp. radicis-lycopersici (Jarvis and Shoemaker 1978). The production of the antifungal metabolite phenazine-1-carboxamide (PCN) is crucial for this beneficial activity (Chin-A-Woeng et al. 1998). In addition, PCL1391 produces hydrogen cyanide (HCN), chitinase, and protease activity. PCN belongs to the class of phenazines, a class of heterocyclic antifungal compounds with broad spectrum activity, to which pyocyanin and phenazine-1-carboxylic acid also belong (Turner and Messenger 1986). The PCN biosynthetic operon was identified previously (Chin-A-Woeng et al. 2001a), and we have shown that expression of the biosynthetic operon is under regulation of quorum sensing (Chin-A-Woeng et al. 2001b). In gram-negative bacteria, this cell-cell communication system relies on diffusible $N$-acylhomoserine lactone ( $N$-AHL) signal molecules to monitor the size of its population (Bassler 2002; Bauer and Coplin 2003; Loh 2002; Newton and Fray 2004; Swift et al. 2001; Von Bodman et al. 2003; Winzer et al. 2002). Quorum sensing is usually based on the action of two proteins that belong to the LuxI and LuxR family of two-component regulatory systems (Latifi et al. 1995; Throup et al. 1995). LuxI homologs synthesize an $N$-acyl-L-homoserine lactone signal that can diffuse through the cell envelope (Hanzelka and Greenberg 1996). A transcriptional regulator, a LuxR homolog, is activated by its cognate population density-dependent $\mathrm{N}$-AHL signal molecule (Zhu and Winans 1999). In addition, the signal is often amplified by an auto-regulatory loop through which the autoinducer synthase is positively regulated (Salmond et al. 1995). The luxI and luxR homologs $p h z I$ and $p h z R$ are essential components in regulating phenazine production and are conserved in three genetically characterized phenazine-producing Pseudomonas biocontrol strains (Chin-A-Woeng et al. 2001b; Mavrodi et al. 1997; Wood et al. 1997). The genes are needed for the production of the autoinducer signal $N$-hexanoyl-L-homoserine lactone $\left(\mathrm{C}_{6}\right.$-HSL) and, consequently, for the production of $\mathrm{PCN}$ in PCL1391 (Chin-A-Woeng et al. 2001b).

In this paper, we describe the identification and characterization of $p s r A$, which is shown to be involved in the repression of PCN production in P. chlororaphis PCL1391. Subsequently, the relation of $p s r A$ to the expression of the quorumsensing genes $p h z I$ and $p h z R, N$-AHL production, and its own regulation was studied. In addition, the effect of the gacS/gacA global regulatory system on $p s r A$ gene expression and related downstream effects in PCL1391 was determined, showing that both PsrA and the GacS/GacA regulatory system, either together or alone, are important regulators of phenazine production. 


\section{RESULTS}

Isolation and genetic characterization of $P$. chlororaphis PCL1391 mutants affected in PCN biosynthesis.

In a screening on agar plates and in liquid cultures of 18,000 PCL1391 Tn5luxAB transconjugants, mutant PCL1111 was selected for its stronger blue-green pigmentation, which is indicative for an increased PCN production. The chromosomal regions flanking the Tn5luxAB insertion of PCL1111 were recovered in plasmid pMP6005 (Table 1). Analysis of $3.6 \mathrm{~kb}$ of the nucleotide sequence flanking the transposon (Fig. 1) revealed the Tn5 transposon insertion in a 708-bp gene encoding a deduced 236-amino acid protein with $89 \%$ identity to PsrA (Pseudomonas sigma regulator) (Table 2) of P. putida WCS358 (Kojic and Venturi 2001). The predicted PsrA protein from strain PCL1391 has a conserved helix-turn-helix motif in its N-terminus. Based on the localization and similarity of the helixturn-helix motif, PsrA is grouped together with the TetR/AcrR family of bacterial transcriptional regulators (Prosite accession number PS01081), which also includes EnvR from Escherichia coli, MtrR from Neisseria gonorrhoeae, and TcmR from Strep- tomyces glaucescens. A PsrA-binding site CAAACAAGTGTT TG matching the palindromic consensus $\mathrm{C} / \mathrm{GAAACN}_{2-4} \mathrm{GTT}$ TG/C (Kojic et al. 2002) was identified in the promoter region of the psrA gene of strain PCL1391 at nucleotide positions -16 to $-30 \mathrm{bp}$, relative to the ATG codon. A very similar sequence

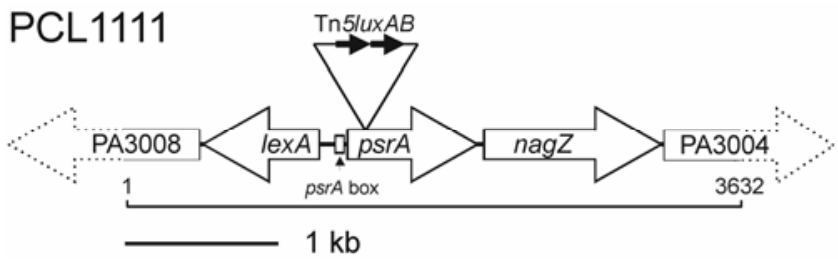

Fig. 1. Schematic representation of the $\mathrm{Tn} 5$ insertion in the Pseudomonas chlororaphis PCL1391 mutant derivative PCL1111, as revealed by nucleotide sequencing of the Tn5 flanking regions. Location of the Tn5transposon insertion, direction of the luxAB reporter genes on the transposon, and putative $p s r A$ binding site are indicated. lexA, gene encoding LexA repressor protein; psrA, Pseudomonas sigma regulator; nag $Z, \beta-N$ acetyl-D-glucosaminidase; other gene names refer to the gene symbols as annotated in the Pseudomonas aeruginosa PAO1 genome (Stover et al. 2000 ). Black arrows indicate the $l u x A B$ genes of the $\operatorname{Tn} 5$ transposon.

Table 1. Microorganisms and plasmids

\begin{tabular}{|c|c|c|}
\hline Strains and plasmids & Relevant characteristics & Reference or source \\
\hline \multicolumn{3}{|l|}{ Bacterial strains } \\
\hline PCL1391 & $\begin{array}{l}\text { Wild-type Pseudomonas chlororaphis, producing phenazine-1-carboxamide and biocontrol } \\
\text { strain of tomato foot and root rot caused by Fusarium. oxysporum f. sp. radicis-lycopersici }\end{array}$ & Chin-A-Woeng et al. 1998 \\
\hline PCL1392 & lacZ-tagged derivative of PCL1391 with the same root-colonising ability as the wild type & Chin-A-Woeng et al. 1998 \\
\hline PCL1103 & PCL1391 phzI::Tn5luxAB & Chin-A-Woeng et al. 2001b \\
\hline PCL1104 & PCL1391 phzR::Tn5luxAB & Chin-A-Woeng et al. 2001b \\
\hline PCL1111 & PCL1391 psrA::Tn5luxAB & This study \\
\hline PCL1119 & PCL1391 phzB::Tn5luxAB & Chin-A-Woeng et al. 1998 \\
\hline PCL1123 & PCL1391 gacS:: Tn5luxAB & This study \\
\hline PCL1138 & PCL1123 derivative, gacS::Tn5luxAB, psrA ${ }^{-}$ & This study \\
\hline PCL1139 & PCL1111 derivative, psrA::Tn5luxAB, gacS ${ }^{-}$ & This study \\
\hline PCL1140 & PCL1103 derivative, phzI::Tn5luxAB, psrA- & This study \\
\hline PCL1142 & PCL1104 derivative, $p h z R:: \operatorname{Tn} 5 \operatorname{luxAB}, p s r A^{-}$ & This study \\
\hline PCL1144 & PCL1119 derivative, $p h z B:: \operatorname{Tn} 5 \operatorname{lux} A B, p s r A^{-}$ & This study \\
\hline PCL1146 & PCL1103 derivative, phzI::Tn5luxAB, gacS ${ }^{-}$ & This study \\
\hline PCL1148 & PCL1104 derivative, phzR::Tn5luxAB, gacS - & This study \\
\hline PCL1150 & PCL1119 derivative, phzB::Tn5luxAB, gacS ${ }^{-}$ & This study \\
\hline PCL1186 & PCL1391, psrA & This study \\
\hline PCL1187 & PCL1391, nagZ & This study \\
\hline PCL1196 & PCL1111 harboring pMP6579 & This study \\
\hline PCL1197 & PCL1119 harboring pBBR1MCS-5 & This study \\
\hline PCL1198 & PCL1119 harboring pMP6579 & This study \\
\hline $\mathrm{DH} 5 \alpha$ & $\begin{array}{l}\text { endAl gyrA96 } h r d R 17\left(r K^{-}-m K^{-}\right) \text {supE } 44 \text { recAl; general purpose Escherichia coli host strain } \\
\text { used for transformation and propagation of plasmids }\end{array}$ & Hanahan 1983 \\
\hline CV026 & Chromobacterium violaceum $N$-acylhomoserine lactone reporter strain & McClean et al. 1997 \\
\hline \multicolumn{3}{|c|}{ 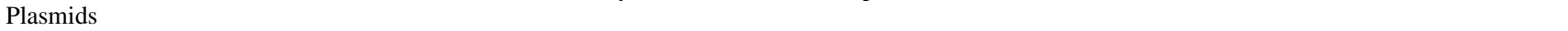 } \\
\hline pRL1063a & $\begin{array}{l}\text { Plasmid harboring } \operatorname{Tn} 5 \text { transposon containing promoterless } \operatorname{lu} x A B \text { and a kanamycin resistance } \\
\text { marker }\end{array}$ & Wolk et al. 1991 \\
\hline $\mathrm{pIC} 20 \mathrm{H}$ & General-purpose cloning vector with a carbenicillin resistance $\left(\mathrm{Cb}^{\mathrm{r}}\right)$ marker & Marsh et al. 1984 \\
\hline pIC20R & General-purpose cloning vector with $\mathrm{C} \mathrm{Cb}^{\mathrm{r}}$ marker & Marsh et al. 1984 \\
\hline pBBR1MCS5 & General-purpose cloning vector with a gentamycin resistance marker & Kovach et al. 1995 \\
\hline pMP5000 & $\begin{array}{l}\text { pIC20H with the tetracycline resistance }\left(\mathrm{Tc}^{\mathrm{r}}\right) \text { cassette from pWTT2081 in the multicloning } \\
\text { site, } \mathrm{Tc}^{\mathrm{r}}, \mathrm{Cb}^{\mathrm{r}}\end{array}$ & Van der Bij et al. 1996 \\
\hline pME6010 & $\begin{array}{l}\text { E. coli/Pseudomonas shuttle vector, stably maintained in Pseudomonas species without } \\
\text { antibiotic pressure, } \mathrm{Km}^{\mathrm{r}}\end{array}$ & Heeb et al. 2000 \\
\hline pMP6005 & $\begin{array}{l}\text { pRL1063a-based plasmid recovered from chromosomal DNA of PCL1111 after digestion with } \\
\text { EcoRI }\end{array}$ & This study \\
\hline pMP6015 & $\begin{array}{l}\text { pIC20R with a } K p n I / E c o R I ~ 0.5-k b \text { internal PCR fragment of } p s r A \text { and a tetracycline marker } \\
\text { from pMP5000 inserted in the multicloning site used to construct strains PCL1138, PCL1140, } \\
\text { PCL1142, PCL1144, and PCL1186. }\end{array}$ & This study \\
\hline pMP6016 & $\begin{array}{l}\text { pIC20R with a KpnI/EcoRI 0.3-kb internal PCR fragment of } g a c S \text { and a tetracycline marker } \\
\text { from pMP5000 inserted in the multicloning site used to construct strains PCL1139, PCL1146, } \\
\text { PCL1148, and PCL1150. }\end{array}$ & This study \\
\hline pMP6049 & $\begin{array}{l}\text { pIC20H-derived plasmid harboring an internal PCR fragment of the nagZ gene of PCL1391 and } \\
\text { a tetracycline cassette from pMP5000, used as a Pseudomonas suicide construct for } \\
\text { homologous recombination to construct PCL1187. }\end{array}$ & This study \\
\hline pMP6579 & pBBR1MCS5-derived plasmid harboring the psrA gene and promoter region of PCL1391. & This study \\
\hline
\end{tabular}


GAAACTGCACTTTG was also identified in the promoter region of rpoS in strain PCL1391 (G. Girard, unpublished data). Analysis of the $p h z I$ and $p h z R$ promoter regions did not reveal an indication for the presence of a psrA binding site.

The psrA gene is the first gene of an operon consisting of at least three genes (Fig. 1). The order and identity of genes thus far analyzed is the same as in $P$. aeruginosa PAO1 (Stover et al. 2000), P. putida KT2440 (Nelson et al. 2002), and $P$. syringae DC3000 (Buell et al. 2003). Downstream of $p s r A$, spaced by a 214-bp intergenic region, a 999-bp gene with $82 \%$ identity to the nagZ gene of $P$. aeruginosa PAO1 is located. nagZ encodes a $\beta$ - $N$-acetylglucosaminidase with a role in peptidoglycan synthesis and recycling. This gene is followed by a partially analyzed open reading frame with homology to a sequence encoding a putative nucleoside phosphorylase (homologous to gene PA3004 of $P$. aeruginosa PAO1; Fig. 1). Introduction of a mutation in the nagZ gene by single homologous recombination with plasmid pMP6049 (Table 1), containing a 798-bp $n a g Z$ internal fragment, resulted in mutant PCL1187, which appeared to display the same phenotype with respect to the production of $N$-AHLs and PCN as the wild type (data not shown). Therefore, the phenotype of the psrA::Tn5 mutant cannot be explained by polar effects of the transposon insertion on genes downstream of $p s r A$. The divergently transcribed gene upstream of psrA (Fig. 1) is homologous with the lexA genes of $P$. aeruginosa (90\%), P. putida (87\%) (Garriga et al. 1992), and E. coli (41\%) (Brent and Ptashne 1981; Calero et al. 1993; Little et al. 1981).

\section{Characterization of the PCN-overproducing psrA mutant.}

Quantification of PCN by high-performance liquid chromatography (HPLC) analysis showed that PCL1111 exhibited an up to tenfold overproduction of PCN ( 0.2 and $1.7 \mathrm{~g}$ of PCN per liter of King's medium $B(\mathrm{~KB})$ growth medium after 16 and $72 \mathrm{~h}$ of growth, reaching an optical density at $620 \mathrm{~nm}$ $\left(\mathrm{OD}_{620}\right)$ of 3 and 12, respectively; Table 3$)$ as compared with the wild type $(0.06$ and $0.15 \mathrm{~g}$ of PCN per liter of growth medium at an $\mathrm{OD}_{620}$ of 3 and 12, respectively). Introduction of a psrA mutation in the lux reporter strain PCL1119 (phzB::Tn5luxAB) using pMP6015 resulted in strain PCL1144, which exhibited an earlier and a fivefold higher expression of the $p h z$ operon than its parental strain PCL1119 (Fig. 2A). In addition, a 2.5 -fold increased production of $\mathrm{C}_{6}$ - $\mathrm{HSL}$ in $p s r A$ mutant PCL1111 (17.5 $\mathrm{nM})$ in comparison with wild-type

Table 2. Characteristics of Pseudomonas chlororaphis PCL1391 and transposon derivatives

\begin{tabular}{|c|c|c|c|}
\hline \multirow[b]{2}{*}{ Traits } & \multicolumn{3}{|c|}{ Bacterial strains $^{\mathbf{a}}$} \\
\hline & PCL1391 & PCL1111 & PCL1123 \\
\hline Tn5luxAB inserted gene & none & $p s r A$ & $\operatorname{gacS}$ \\
\hline PCN production ${ }^{\mathrm{b}}$ & + & ++++ & - \\
\hline Antifungal activity ${ }^{\mathrm{c}}$ & + & + & - \\
\hline Autoinducer production & + & ++ & \pm \\
\hline $\mathrm{HCN}$ production & + & + & + \\
\hline Protease production & + & + & - \\
\hline Lipase production & + & + & + \\
\hline Chitinase production & + & + & - \\
\hline Motility & + & + & + \\
\hline Tomato root tip colonization ${ }^{\mathrm{d}}$ & + & + & + \\
\hline
\end{tabular}

a $+=$ wild-type level $;++=$ twofold increase $;++++=$ tenfold increase $;-=$ absent, $\pm=$ decreased to $<0.1 \mathrm{nM}$.

${ }^{\mathrm{b}}$ Phenazine-1-carboxamide (PCN) production was determined after $72 \mathrm{~h}$ of growth

${ }^{c}$ Activity was tested in a petri dish assay for antifungal activity (Geels and Schippers 1983) against $F$. oxysporum f. sp. radicis-lycopersici.

${ }^{\mathrm{d}}$ Colonizing ability was tested after seedling inoculation in competition with PCL1392, a Tn5lacZ-tagged derivative of PCL1391 not impaired in root colonization, in a gnotobiotic sand system (Simons et al. 1996).
PCL1391 (7.0 nM) was detected in the growth medium (retardation factor $\left(\mathrm{R}_{\mathrm{f}}\right)=0.36$ ) (Fig. 3A, lanes 1 and 5). The activity detected at the $R_{f}$ value of 0.57 observed for PCL1111 (Fig. $3 \mathrm{~A}$, lane 5) was only detected when larger amounts of culture supernatant extract of the wild type were analyzed and has the same $\mathrm{R}_{\mathrm{f}}$ value as synthetic $\mathrm{C}_{4}$-HSL (Chin-A-Woeng et al. 2001b).

Strain PCL1111 (psrA::Tn5luxAB) was not altered in the production of $\mathrm{HCN}$, protease, and chitinase, as compared with its wild type (Table 2). Motility and its ability to colonize the tomato root system $\left[4.1 \pm 0.3 \log _{10}(\mathrm{PCL} 1111 \mathrm{CFU}+1) / \mathrm{cm}\right.$ of root tip] in competition with the reference strain PCL1392, a lacZ-tagged derivative of the wild-type strain PCL1391, which is not impaired in colonization [3.9 $\pm 0.4 \log _{10}$ (PCL1392 CFU $+1) / \mathrm{cm}$ of root tip], were not affected after seedling inoculation. Since PCN production was elevated in strain PCL1111, this strain was tested for its efficiency to control tomato foot and root rot caused by $F$. oxysporum f. sp. radicis-lycopersici. Although PCL1111 was found to suppress tomato foot and root rot better than the wild type (e.g., 41 vs. $49 \%$ diseased plants, respectively) in three bioassays performed, the differences were not statistically significant (data not shown).

An independently constructed psrA mutant, strain PCL1186, made by homologous recombination, using a pIC20R-derived suicide construct containing a tetracycline resistance cassette and a 600-bp internal fragment of the psrA gene (pMP6015), displayed the same phenotypic characteristics as did PCL1111 (psrA::Tn5luxAB) (Table 3).

\section{Influence of a psrA mutation on autoinducer and $P C N$ production.}

Transcriptional fusions of the $\operatorname{lux} A B$ genes with $p h z I$ in strain PCL1103 (phzI::Tn5luxAB) and with phzR in PCL1104 $(p h z R:: \operatorname{Tn} 5 \operatorname{lu} x A B)$ allowed us to monitor the expression of these genes. Due to the insertional inactivation, these reporter strains do not produce detectable amounts of autoinducers (Fig. 3A, lanes 2 and 3; Table 3) and PCN (Chin-A-Woeng et al. 2001b). To characterize the influence of a psrA mutation on

Table 3. Production of $N$-hexanoyl homoserine lactone $\left(\mathrm{C}_{6}-\mathrm{HSL}\right)$ and phenazine-1-carboxamide (PCN) by Pseudomonas chlororaphis PCL1391 and mutant derivatives

\begin{tabular}{|c|c|c|}
\hline Strain & $\begin{array}{c}\mathrm{C}_{6}-\mathrm{HSL}^{\mathrm{a}} \\
(\mathrm{nM})\end{array}$ & $\begin{array}{c}\mathbf{P C N}^{\mathbf{b}} \\
\text { (g/liter) }\end{array}$ \\
\hline PCL1391 (wild type) & 7 & 0.15 \\
\hline PCL1111 (psrA::Tn5luxAB) & 17.5 & 1.7 \\
\hline PCL1103 (phzI::Tn5luxAB) & n.d. ${ }^{\mathrm{c}}$ & n.d. \\
\hline PCL1104 (phzR::Tn5luxAB) & n.d. & n.d. \\
\hline PCL1123 (gacS::Tn5luxAB) & $<0.1$ & n.d. \\
\hline PCL1186 $\left(p s r A^{-}\right)$ & 17 & 1.8 \\
\hline PCL1140 (phzI::Tn5luxAB, psrA $\left.A^{-}\right)$ & 5 & 0.17 \\
\hline PCL1142 (phzR::Tn5luxAB, psrA-) & 27.5 & 0.09 \\
\hline PCL1196 (PCL1111 pMP6579) & 6.3 & 0.1 \\
\hline PCL1198 (PCL1119 pMP6579) & 5 & n.d. \\
\hline PCL1146 (phzI::Tn5luxAB, gacS $\left.{ }^{-}\right)$ & n.d. & n.d. \\
\hline PCL1148 (phzR::Tn5luxAB, gacS $\left.S^{-}\right)$ & n.d. & n.d. \\
\hline PCL1150 (phzB::Tn5luxAB, gacS $\left.S^{-}\right)$ & $<0.1$ & n.d. \\
\hline PCL1138 (gacS::Tn5luxAB, psrA-) & n.d. & n.d. \\
\hline PCL1139 (psrA::Tn5luxAB, gacS $\left.{ }^{-}\right)$ & n.d. & n.d. \\
\hline
\end{tabular}

a A 100-ml volume of a 72-h King's medium B culture supernatant of the strains was extracted with dichloromethane, and samples equivalent to 20 $\mathrm{ml}$ of culture supernatant were tested in the Chromobacterium thin-layer chromatography overlay assay. Concentration of $\mathrm{C}_{6}$-HSL was calculated from the intensities of spots and a calibration curve of synthetic $\mathrm{C}_{6}$-HSL.

b The cell-free supernatants of culture samples were extracted twice with an equal volume of toluene. PCN was separated by high-performane liquid chromatography, and production in the growth medium was calculated from peak areas using a calibration curve of PCN.

n.d. $=$ not detected 
expression of $p h z I$ and $p h z R, p s r A$ was mutated in PCL1103 (phzI::Tn5luxAB) and PCL1104 (phzR::Tn5luxAB) by homologous recombination using pMP6015, resulting in strains PCL1140 and PCL1142, respectively. Surprisingly, after mutation of psrA, PCN production was restored to wild-type level in the $p h z R$ mutant PCL1104 and the phzI mutant PCL1103, as was judged by restoration of blue/green pigment production on agar plates (data not shown) and quantification of PCN by C18-reverse phase-HPLC analysis of culture supernatant extracts. Strain PCL1140 (phzI::Tn5luxAB, psrA ${ }^{-}$) produced 0.17 $\mathrm{g}$ of PCN per liter of growth medium, and PCL1142 (phzR::Tn5luxAB, psrA $A^{-}$) produced $0.09 \mathrm{~g}$ of $\mathrm{PCN}$ per liter of growth medium (Table 3). Moreover, analysis of cell-free spent culture medium of these double mutants using the Chro- mobacterium $N$-AHL reporter assay showed the production of two compounds with inducer activity. The activities produced by both strains PCL1140 (phzI::Tn5luxAB, psrA-) and PCL1142 ( $p h z R:: \operatorname{Tn} 5 \operatorname{lux} A B, p s r A^{-}$) were present at the same positions as $\mathrm{C}_{6}$-HSL and $\mathrm{C}_{4}$-HSL (Fig. 3B, lanes 3 and 4). For PCL1140 (phzI::Tn5luxAB, psrA $A^{-}$) and PCL1142 (phzR::Tn5luxAB, $p s r A^{-}$), the strains appeared to produce 5.0 and $27.5 \mathrm{nM} \mathrm{C}_{6^{-}}$ HSL, respectively (Table 3). Furthermore, in contrast to strain PCL1103 (phzI::Tn5luxAB), phzI in PCL1140 (phzI::Tn5luxAB, $p s r A^{-}$) was induced in the absence of exogenously added synthetic $\mathrm{C}_{6}$-HSL (Fig. 2B). Expression of phzI in PCL1140 (phzI::Tn5luxAB, psrA-) i) was induced at the start of the stationary phase (Fig. 2B), ii) reached a basic level higher than that of PCL1103 (phzI::Tn5luxAB) (Fig. 2B), and iii) reached a
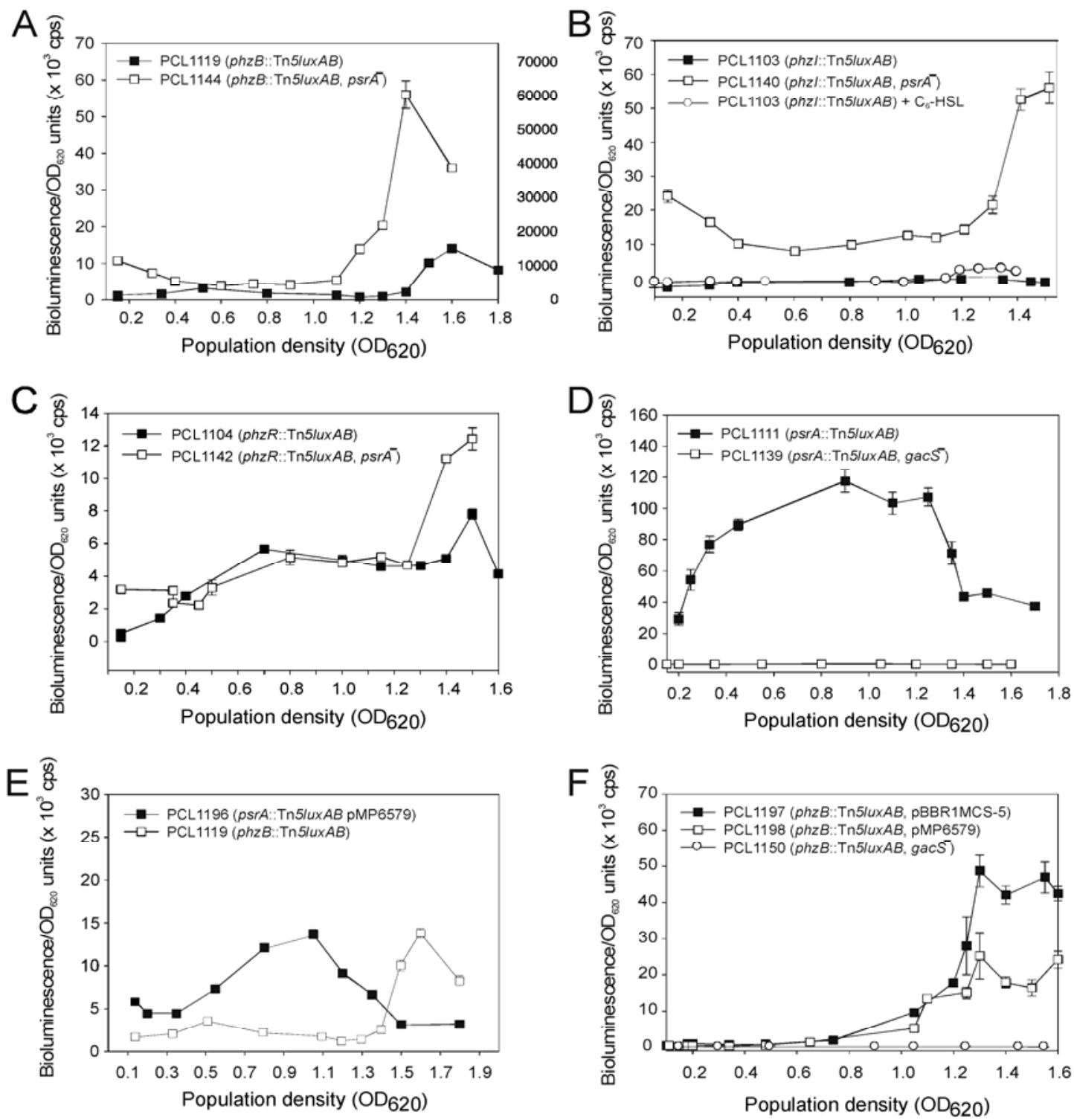

Fig. 2. Expression of the regulatory genes phzI, phzR, and psrA, and of the phenazine-1-carboxamide (PCN) biosynthetic operon of Pseudomonas chlororaphis PCL1391 in psrA and gacS mutant strains. Strains were grown in KB medium. Where indicated, synthetic $N$-hexanoyl-L-homoserine lactone was added to the culture to a concentration of $5 \mu \mathrm{M}$ at the initial optical density at $620 \mathrm{~nm}$ of 0.1 . Values depicted in the panels are values for the luminescence measured in counts per seconds (cps) per optical density unit during growth in time. A through $\mathbf{C}$, Comparison of the expression of the biosynthetic $p h z B$ (PCL1144, panel A) and the regulatory $p h z I$ (PCL1140, panel B) and $p h z R$ genes (PCL1142, panel C) in $p s r A$-deficient backgrounds versus in their parental backgrounds (PCL1119, PCL1103, PCL1104, respectively). D, Expression of psrA::Tn5luxAB in a gacS-deficient background (PCL1139) versus its $p s r A$ mutant background (PCL1111). E, Expression of psrA::Tn5luxAB in PCL1196 (PCL1111 harboring a multicopy plasmid pMP6579 with the $p s r A$ gene). For comparison, the expression of $p h z B:: T n 5 l u x A B$ in PCL1119 is also included. F, Expression of the PCN biosynthetic genes in a $p s r A$ multicopy background (PCL1198) and in a gacS-deficient background (PCL1150) versus in its parental background PCL1197 (phzB::Tn5luxAB, pBBRMCS-5). Data points were sampled in triplicate. If error bars are not indicated, standard errors were too small to visualize in the graph. Expression studies were performed at least twice in independent experiments with similar results. 
higher level in the stationary phase than when synthetic $\mathrm{C}_{6^{-}}$ HSL $(5 \mu \mathrm{M})$ was added to PCL1103 (Fig. 2B). A small positive effect of the $p s r A$ mutation on the expression of $p h z R$ was also observed at the onset of the stationary phase in PCL1142 (Fig. 2C) and was consistent with the 1.2-fold increased production of $\mathrm{C}_{6}$-HSL (Fig. 3B, lane 4; Table 3).

\section{Analysis of psrA expression during growth and autoregulation.}

Expression of psrA during growth, starting at $\mathrm{OD}_{620}=0.1$, was analyzed, using PCL1111 ( $p s r A:: \operatorname{Tn} 5 l u x A B$ ). Expression of $p s r A$ reached a maximum in the late exponential phase of growth $\left(\mathrm{OD}_{620}=1.2\right)$, followed by a rapid decrease (Fig. 2D). The moment of downregulation coincided with the moment at which $p h z B$ expression was induced (Fig. 2A).

To study the expression of psrA::Tn5luxAB in a psrA-positive background, the complete $p s r A$ gene, including $199 \mathrm{bp}$ of its putative promoter region, was amplified with PCR and was cloned into $\mathrm{pBBR} 1 \mathrm{MCS} 5$, resulting in plasmid pMP6579. Introduction of psrA (pMP6579) into PCL1111 (psrA::Tn5luxAB) reduced PCN production to approximately wild-type levels (Table 3 , PCL1196). Similarly, $\mathrm{C}_{6}$-HSL production was restored to approximate wild-type levels, from 25 to $6.3 \mathrm{nM}$, in PCL1196
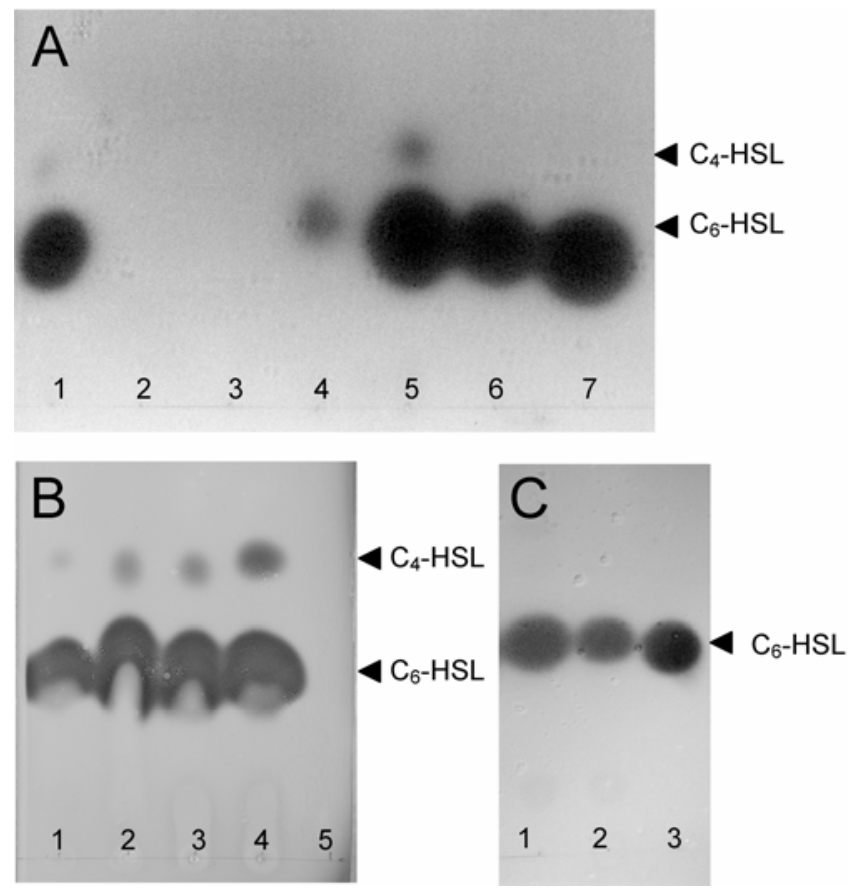

Fig. 3. C18-reverse phase thin-layer chromatography (TLC) analysis of $N$ acyl-L-homoserine lactones produced by Pseudomonas chlororaphis PCL1391 and mutant derivatives. A volume of $100 \mathrm{ml}$ of a 72-h King's medium B culture supernatant of the strains was extracted with dichloromethane, and samples equivalent to $20 \mathrm{ml}$ of culture supernatant were tested in the Chromobacterium TLC overlay assay. A, Autoinducer profiles of regulatory and biosynthetic mutants of $P$. chlororaphis PCL1391. Lane 1, PCL1391 wild type, lane 2, PCL1103 (phzI::Tn5luxAB); lane 3, PCL1104 (phzR::Tn5luxAB); lane 4, PCL1123 (gacS::Tn5luxAB); lane 5, PCL1111 (psrA::Tn5luxAB); lane 6, PCL1119 (phzB::Tn5luxAB); lane 7, synthetic $N$-hexanoyl-L-homoserine lactone $\left(\mathrm{C}_{6}\right.$-HSL) standard $\left(1 \times 10^{-10} \mathrm{~mol}\right) . \quad \mathbf{B}, \mathrm{C}_{6}$-HSL production by Pseudomonas chlororaphis PCL1391 and psrA mutant derivatives. Lane 1, PCL1391 wild type; lane 2, PCL1111 (psrA::Tn5luxAB); lane 3, PCL1140 (phzI::Tn5luxAB, psrA); lane 4, PCL1142 (phzR::Tn5luxAB, psrA); lane 5, PCL1139 (psrA::Tn5luxAB, gacS). C, $\mathrm{C}_{6}$-HSL production of the complemented P. ororaphis PCL1111 (psrA::Tn5luxAB). Lane 1, PCL1111 (psrA::Tn5luxAB); lane 2, PCL1111 harboring pMP6579 (psrA); lane 3, synthetic $\mathrm{C}_{6}$-HSL standard $\left(1 \times 10^{-10} \mathrm{~mol}\right)$. Experiments were performed at least twice with similar results.
(Fig. 3C, lane 2; Table 3). When the expression of psrA was assessed in a psrA-positive background using PCL1196, maximal expression $\left(1.4 \times 10^{4}\right.$ counts per second [cps]) (Fig. 2E) was tenfold lower than in the absence of $p s r A\left(1.2 \times 10^{5} \mathrm{cps}\right)$ (Fig. 2D).

To assess the repressing role of psrA on phz expression, pMP6579 was also transferred to PCL1119 (phzB::Tn5luxAB). The characteristic population density-dependent expression of the $p h z B$ gene was observed, but the overall expression was lower in a psrA-multicopy background in PCL1198 as compared with PCL1119 harboring the empty vector (PCL1197) (Fig. 2F). Multiple copies of psrA in strain PCL1198 or wild type caused a slightly repressing effect on production of $\mathrm{C}_{6}$ HSL $(5.0 \mathrm{nM})$ as compared with that in the parental strains carrying the empty control vector $(7.0 \mathrm{nM})$ (Table 3$)$.

\section{psrA expression in a gacS-deficient background.}

Strain PCL1123 (gacS::Tn5luxAB) was identified as being impaired in production of $\mathrm{PCN}$, protease, and chitinase (but not $\mathrm{HCN}$ and lipase) and, consequently, in the inhibition of $F$. oxysporum f. sp. radicis-lycopersici (Table 2). Similarly, gacS mutants of $P$. aeruginosa PAO1 (Reimmann et al. 1997) and $P$. aureofaciens 30-84 (Chancey et al. 1999) are disturbed in quorum sensing and phenazine production. The production of autoinducers in PCL1123 ( $\operatorname{gacS}:$ :Tn5luxAB) is severely reduced (to $<0.1 \mathrm{nM}$ ) as compared with that in the wild type (Table 3; Fig. 3A, lanes 1 and 4), and expression of the phz genes is abolished in the gacS-deficient $p h z B$ reporter strain PCL1150 (Fig. 2F), which is also reflected in gacS mutants of the quorumsensing reporters, since phzI expression in the double mutant PCL1146 (phzI::Tn5luxAB, gac $S^{-}$) cannot be induced by the addition of exogenous $\mathrm{C}_{6}$-HSL and $p h z R$ expression is repressed in the $g a c S$-deficient $p h z R$ reporter PCL1148 (data not shown).

To analyze the effect of $g a c S$ on the expression of $p s r A$, the reporter strain PCL1111 ( $\operatorname{sr} A:: \operatorname{Tn} 5 \operatorname{lux} A B)$ was mutated in gacS by homologous recombination using plasmid pMP6016, resulting in strain PCL1139. Expression of psrA (Fig. 2D) was abolished in PCL1139, showing that the expression of psrA is dependent upon the presence of $g a c S$. PCN production by PCL1139 was not detected (as judged from HPLC analysis of spent culture medium extracts) (Table 3 ); neither were $\mathrm{C}_{6}$-HSL and $\mathrm{C}_{4}$-HSL detected in extracts of PCL1139 spent culture medium (Fig. 3B, lane 5). The reciprocal mutant PCL1138 ( gacS::Tn5luxAB, psrA ${ }^{-}$) displays a phenotype identical to PCL1139 (data not shown).

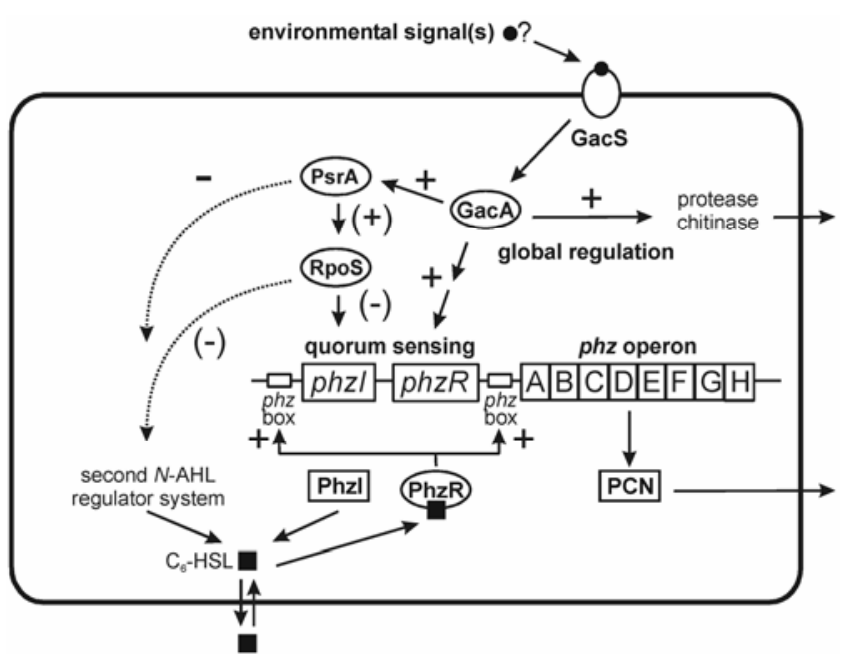

Fig. 4. Model for the regulation of the phenazine (phz) biosynthetic operon in Pseudomonas chlororaphis PCL1391. Abbreviations: A to H, phzA to $p h z H$ genes; $\mathrm{C}_{6}$-HSL, $N$-hexanoyl- L -homoserine lactone; $N$-AHL, $N$-acylL-homoserine lactone; PCN, phenazine-1-carboxamide. 


\section{DISCUSSION}

Production of secondary metabolites, including phenazine antibiotics, in Pseudomonas spp. appears to be controlled by complex regulation systems, including quorum sensing and a two-component global regulatory GacS/GacA system (Chancey et al. 1999; Reimmann et al. 1997). Other regulators of phenazine production in $P$. aeruginosa PAO1 include RsmA/RsmZ (regulator of secondary metabolites) (Chatterjee et al. 1995; Cui et al. 1995; Pessi et al. 2001), the stationary phase sigma factor RpoS (Suh et al. 1999; Venturi 2003), a LuxR-type repressor protein QscR (Chugani et al. 2001), the global repressor MvaT (Diggle et al. 2002), and the Sm-like protein Hfq (Sonnleitner et al. 2003). In addition, a negative regulator RpeA (repressor of phenazine expression) was identified in Pseudomonas aureofaciens 30-84 (Whistler and Pierson 2003).

In previous studies, we have identified genes involved in regulation of phenazine biosynthesis (Chin-A-Woeng et al. 2001b). In this paper, we describe additional genes contributing to the regulation of phenazine biosynthesis. Screening for PCL1391 transposon mutants for increased PCN production resulted in the identification of the psrA gene (Fig. 1). The transcriptional activity of $p s r A$ was profiled along with the quorum-sensing regulatory genes and $p h z$ biosynthetic genes during growth. Although our results do not indicate that one or more additional factors (for example a signal compound) are required for the activity of PsrA, this cannot be excluded. It is not known if PsrA requires additional factors for its activity. Our results show that, in addition to the already identified $p h z I / p h z R$ and gac regulatory genes, the $p s r A$ gene also significantly contributes to the regulation of PCN biosynthesis by (at least partly) influencing production of $\mathrm{C}_{6}$-HSL and $\mathrm{C}_{4}-\mathrm{HSL}$ (Fig. 3). We show the repressing effect of psrA expression on the quorum-sensing genes, $p h z$ biosynthetic genes, and on itself (Fig. 2). Moreover, the expression of $p s r A$ appears to be dependent upon the presence of gacS (also called lemA and apdA; Hrabak and Willis, 1992), the sensor kinase part of a two-component global regulatory system that is also involved in regulation of quorum sensing and production of secondary metabolites (Reimmann et al. 1997; Sacherer et al. 1994). On the basis of our results, we present a model for the regulation of PCN production of PCL1391 by PsrA, which includes regulators involved in quorum sensing, global regulation, and stress signaling (Fig. 4; discussed below).

The deduced amino acid sequence shows that PsrA belongs to the TetR family of transcriptional regulators. Many of the gene products in this family function as repressors in regulating the level of susceptibility to hydrophobic antibiotics and detergents. Mutation of psrA resulted in a more than twofold and, after prolonged growth, up to tenfold increase in PCN production and in substantially increased autoinducer production in KB medium (Fig. 3A, lane 5). The significantly increased levels of PCN and $N$-AHLs produced in the psrA mutant can be explained by the increased expression of the $p h z I, p h z R$, and phenazine biosynthetic genes (Fig. 2A through C). Our data show that PsrA contributes to an additional level of regulation in PCL1391 by repressing quorum sensing and quorum sensing-regulated genes. In addition, psrA is also indicated to repress its own expression, as was indicated by the position of the PsrA binding site in the $p s r A$ promoter region $(-16$ to -30 bp relative to the ATG codon) and was shown by expression studies (Figs. 2D and E).

PsrA was identified as a positive regulator of $r p o S$ expression in $P$. putida WCS358 and $P$. aeruginosa PAO1 (Bertani et al. 2003; Kojic and Venturi 2001). The stationary-phase sigma factor RpoS, or $\sigma^{\mathrm{s}}$, is a stress response protein involved in the regulation of many stationary phase, stress-related, and other proc- esses in Pseudomonas (Sarniguet et al. 1995; Schuster et al. 2004; Suh et al. 1999), including phenazine production in $P$. aeruginosa. Regulation of phenazine production in $P$. aeruginosa PAO1 involves two systems, the Rhl and Las quorum-sensing systems. There are no indications that Rhl- or Las-like systems are present in PCL1391, neither does P. aeruginosa PAO1 posses $p h z I / R$ genes. Recently, we have studied the role of RpoS in PCL1391 in more detail, showing a clear regulatory effect (direct or indirect) of RpoS on quorum sensing and PCN production (G. Girard, unpublished data), and therefore, we included a role of RpoS in our model of PCN regulation (Fig. 4).

The increased autoinducer production in a PCL1391 psrA mutant (Fig. 3A) is in contrast with P. aeruginosa PAO1 and $P$. putida WCS358, in which no difference in the amounts of autoinducer molecules in supernatants of psrA null mutants and its wild type were detected (Kojic and Venturi 2001). The distinct quorum-sensing systems in the three strains may have contributed to the different data. Since $p s r A$ was identified as an inducer of RpoS expression, we assume that in a psrA mutant of PCL1391, rpoS expression is reduced, which would lead to higher expression levels of the $p h z I / p h z R$ genes and, consequently, of the phz biosynthetic operon. The rpoS promoter of PCL1391 (G. Girard, unpublished data) indeed contains a putative binding site for the PsrA regulator $\left({ }^{-177}\right.$ GAAACTGCA CTTTG $^{-164}$, consensus underlined). The sequence is nearly identical to the consensus recognition sequence in the promoter of rpoS of P. putida WCS358 in which binding of PsrA to the promoter was mapped (Kojic et al. 2002). Furthermore, recent data show a lower rpoS expression level in a PCL1391 psrA mutant (G. Girard, personal communication).

Surprisingly, a psrA mutation can compensate for mutations in $p h z I$ and $p h z R$ (Fig. 2B and C) in that it enables the mutants to produce PCN and autoinducer compounds (Fig. 3B, lanes 2 and 3). Studies with reporter strains in which psrA is mutated show that the expression of $p h z I, p h z R$, and of the $p h z$ biosynthetic genes is increased (Fig. 2A through C). Single mutation of $p h z I$ or $p h z R$ abolishes autoinducer production (Fig. 3A; lanes 2 and 3) as well as PCN production. However, we observe that in a $p h z I / p s r A$ double mutant the $p h z I$ promoter is induced in a population density-dependent manner (Fig. 2B) and that $\mathrm{PCN}$ production is restored to wild-type levels. Moreover, two compounds with autoinducer activity are detectable in the phzI/psrA and phzR/psrA double mutants (Fig. 3B, lanes 3 and 4). Taking into account the structural requirements of molecules inducing the Chromobacterium $N$-AHL reporter (McClean et al. 1997) and their migration characteristics, these two compounds are most likely $\mathrm{C}_{4}$-HSL and $\mathrm{C}_{6}$-HSL. Since the inactivation of $p s r A$ can restore the synthesis of autoinducer activity and PCN in a previously defective strain (Chin-A-Woeng et al. 2001), we hypothesize that PsrA also acts either as a repressor of a second system capable of producing $N$-AHLs or acts indirectly, via induction of $r p o S$ expression, leading to repression of the second $N$-AHL-producing system (Fig. 4). The observed PCN production by the $p s r A / p h z R$ double mutant PCL1142 indicates that there is another regulator for the biosynthetic operon, which could be another LuxR homolog. Alternatively, we speculate that PsrA might act on a quorum sensing-independent regulator of the phenazine biosynthethic operon, especially since the relatively high AHL production in PCL1142 does not result in PCN levels higher than wild-type levels (Table $3)$. An interesting candidate for such a regulator is the recently identified RpeA (repressor of phenazine expression) protein identified in $P$. aureofaciens 30-84 (Whistler and Pierson 2003). In the absence of this negative regulator, $p h z R$ was not required and phenazine production in a $p h z R / r p e A$ double mutant did not differ from the wild-type $P$. aureofaciens 30-84 (Whistler and Pierson 2003). 
In several Pseudomonas strains, more than one quorumsensing system has been identified. The CsaI-CsaR system has been identified as a second quorum-sensing system in the highly related phenazine-producing $P$. aureofaciens 30-84 (Zhang and Pierson 2001). However, this system did not regulate phenazine production but was, rather, involved in protease production and biosynthesis of cell surface components and produces signals different from those produced by PhzI.

In many gram-negative bacteria, the GacS/GacA regulatory system plays a role in the control of extracellular products and virulence (Ahmer et al. 1999; Laville et al. 1992; Mahajan et al. 1999; Sacherer et al. 1994). The histidine sensor kinase GacS relays environmental information to GacA (Hrabak and Willis 1992; Rich et al. 1994) and is part of a two-component regulatory system together with GacA (Appleby et al. 1996; Heeb and Haas 2001; Pernestig et al. 2001). The nature of the environmental stimulus for GacS is not known. A gacS mutant of PCL1391 does not produce sufficient amounts of $\mathrm{C}_{6}$-HSL to mount PCN production. In addition, secreted protease and chitinase activities are lacking (Table 2). The global activator GacA is a member of the FixJ family of response regulators (Laville et al. 1992) and is a well-conserved response regulator identified in many gram-negative bacteria, including Pseudomonas spp. (de Souza et al. 2003; Heeb and Haas 2001). GacA i) positively regulates production of secondary metabolites in $P$. fluorescens CHA0 (Sacherer et al. 1994), ii) regulates pyocyanin production in $P$. aeruginosa $\mathrm{PAO} 1$ by controlling the production of $\mathrm{C}_{4}$-HSL (Reimmann et al. 1997), and iii) mediates the synthesis of autoinducers in P. aureofaciens 30-84 (Chancey et al. 1999). Transcription of rpoS, assessed with an rpoS-lacZ transcriptional fusion, was positively influenced by GacS and GacA in P. fluorescens Pf-5 (Whistler et al. 1998). The GacA/GacS two-component system has a clear positive effect on transcription of rpoS and quorum-sensing genes, but whether this is directly or through another regulator was not known to date. Our new data now show that gacS expression has a positive influence on the expression of $p s r A$ (Fig. 2D). Since $g a c S$ expression is required for expression of $p s r A$, and psrA appears to be necessary for induction of RpoS (Kojic and Venturi 2001; G. Girard, unpublished data), we propose that the GacS/GacA system is linked to RpoS via the PsrA regulator (Fig. 4).

Although the psrA mutation can suppress the effect of a mutation in one of the quorum-sensing genes in strain PCL1391 (Fig. 3B, lanes 3 and 4) by inducing a second, yet to be identified autoinducer synthase system, the presence of gacS is needed for PCN production, since gacS/psrA double mutants do not produce PCN. The observation that a psrA mutant is not affected in the production of other secondary metabolites and exoenzymes indicates that psrA acts downstream of $\mathrm{GacS} / \mathrm{GacA}$ and confirms the role of $\mathrm{GacS} / \mathrm{GacA}$ as a global regulatory system that not only regulates $\mathrm{PCN}$ biosynthesis but also that of chitinase and protease (Table 2).

\section{MATERIALS AND METHODS}

\section{Microorganisms and media.}

The bacterial strains and plasmids used are listed in Table 1. KB (King et al. 1954) was used for routinely culturing Pseudomonas strains. E. coli and the Chromobacterium violaceum were grown in LB medium (Sambrook and Russel 2001). Solid growth media contained $1.8 \%$ agar (Difco Laboratories, Detroit). Kanamycin $(50 \mu \mathrm{g} / \mathrm{ml})$, tetracycline $(80 \mu \mathrm{g} / \mathrm{ml})$, carbenicillin $(50 \mu \mathrm{g} / \mathrm{ml})$, and gentamycin $(10 \mu \mathrm{g} / \mathrm{ml})$ were added for antibiotic selection of Pseudomonas strains, E. coli, and Chromobacterium violaceum, as applicable. For selection of $E$. coli $20 \mu \mathrm{g}$ of tetracycline per $\mathrm{ml}$ was used.

\section{DNA modifications.}

Digestion with restriction endonucleases, ligation, transformation of $E$. coli cells with plasmid DNA, and polymerase chain reaction using Pwo polymerase (Roche Molecular Biochemicals, Basel, Switzerland) were performed using standard molecular biological protocols (Sambrook and Russel 2001). Nucleotide sequencing was performed by Eurogentec B.V. (Herstal, Belgium) using AB1377-based fluorescent sequencing technology and Baseclear (Leiden, The Netherlands) using dye terminator chemistry or dye-primer chemistry. Computer analysis of protein and nucleotide sequences was performed with the European Molecular Biology Open Software Suite (EMBOSS) version 2.0.1 (Rice et al. 2000). The PCL1391 chromosomal sequences containing gacS and $p s r A$ were deposited in GenBank under accession numbers AF502252 and AF502251, respectively.

\section{Isolation and characterization of mutants.}

A mutant library of PCL1391 consisting of 18,000 transposon mutants was established using pRL1063a (Wolk et al. 1991), harboring a Tn5 transposon carrying promoterless lux $A B$ reporter genes. Mutants were selected for absence of or change in PCN-related pigment production either on LB agar plates or in 200- $\mu$ l liquid KB cultures grown in 96-well microtiter plates for 3 days (Chin-A-Woeng et al. 1998). Phenotypic characterization of the mutants for production of PCN, hydrogen cyanide, chitinase, or protease for motility (Chin-AWoeng et al. 1998) and for tomato root-colonizing ability (Simons et al. 1996) was performed as previously described. Tomato- $F$. oxysporum f. $\mathrm{sp}$. radicis-lycopersici biocontrol assays were also performed as described previously (Chin-AWoeng et al. 1998).

Since the Tn 5 transposon in the transconjugants contains an origin of replication that functions in E. coli (Wolk et al. 1991), chromosomal DNA regions flanking the transposon were recovered from the genome by excision with EcoRI, followed by circularization. After transfer to E. coli, the recovered constructs were analyzed by nucleotide sequencing. $\mathrm{Nu}-$ cleotide sequencing of the flanking regions was performed with unique primers oMP458 (5'-TACTAGATTCAATGCTAT CAATGAG-3') and oMP459 (5'-AGGAGGTCACATGGAA TATCAGAT- $3^{\prime}$ ) directed to the left and right ends of the Tn5 transposon, respectively.

\section{Phenazine extractions and analyses.}

Phenazines were extracted as described previously (Chin-AWoeng et al. 1998). The cell-free supernatants of culture samples were adjusted to $\mathrm{pH} 2$ with $\mathrm{HCl}$ and were extracted twice with an equal volume of toluene. The solvent phase was removed with a rotary evaporator and the residue was dissolved in $20 \%$ (vol/vol) acetonitrile. PCN was separated by HPLC,

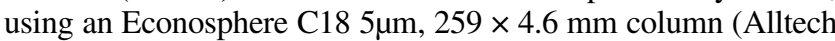
Associates, Inc., Deerfield, IL, U.S.A.) at $30^{\circ} \mathrm{C}$, with a linear gradient of 20 to $80 \%$ acetonitrile acidified with $0.1 \%$ trifluoroacetic acid and a flow rate of $1 \mathrm{ml} / \mathrm{min}$. Quantification was performed using a calibration curve of purified PCN and HPLC analysis software (Chromeleon software package v6.2; Dionex Corporation, Sunnyvale, CA, U.S.A.).

\section{Detection and quantification of autoinducer activities.}

Autoinducer activity was extracted from $100 \mathrm{ml}$ of supernatant of 16- or 72-h KB culture with dichloromethane. Dichloromethane was added to the supernatant in a ratio of 3:7 dichloromethane/supernatant (vol/vol) and was shaken for $1 \mathrm{~h}$ $(120 \mathrm{rpm})$. The organic phase was removed and dried by evaporation in vacuo (McClean et al. 1997). Supernatant extracts were redissolved in $100 \mu \mathrm{l}$ of $100 \%$ acetonitrile, and subse- 
quently $20 \mu \mathrm{l}$ was fractionated with $\mathrm{C} 18$ thin-layer chromatography (TLC) plates (Merck, Darmstadt, Germany). After development in a solvent mixture of methanol/water (60:40, vol/vol), the plates were dried. TLC plates were overlaid with $30 \mathrm{ml}$ of $0.8 \% \mathrm{LB}$ top agar mixed with $2 \mathrm{ml}$ of a 16-h culture of the Chromobacterium violaceum CV026 indicator strain $(200 \mu \mathrm{l} / \mathrm{ml})$ and kanamycin $(50 \mu \mathrm{g} / \mathrm{ml})$ (McClean et al. 1997). The activity of samples was judged after $16 \mathrm{~h}$ of growth at $28^{\circ} \mathrm{C}$ by the appearance of violet spots caused by violacein production as a result of activation of the reporter genes in the Chromobacterium strain. Amounts of $\mathrm{C}_{6}$-HSL were determined using densiometry calculations of the spots and a calibration curve of standard concentrations of $\mathrm{C}_{6}$-HSL $(5,2,1$, and $0.1 \mathrm{pmol})$, using the Scion Image software package v4.0.2 (Scion Corporation, Frederick, MD, U.S.A.). Synthetic $N$-butanoyl-L-homoserine lactone $\left(\mathrm{C}_{4}\right.$-HSL), $N$-hexanoyl-L-homoserine lactone $\left(\mathrm{C}_{6}\right.$-HSL), and N-octanoyl-l-homoserine lactone $\left(\mathrm{C}_{8}\right.$-HSL) references were provided by P. Williams, University of Nottingham, U.K.

\section{Expression studies \\ using bioluminescent Tn5luxAB reporter strains.}

Expression of Tn5luxAB-tagged genes was determined by quantification of $\operatorname{lux} A B$ activity during culturing. Cells from overnight $\mathrm{KB}$ cultures were washed with fresh medium and resuspended in $\mathrm{KB}$ medium to an optical density at $620 \mathrm{~nm}$ $\left(\mathrm{OD}_{620}\right)$ of 0.1 . Cultures were grown in a volume of $10 \mathrm{ml}$ under vigorous shaking. Growth was followed by measurement of $\mathrm{OD}_{620}$ at regular intervals, and $100-\mu$ samples were taken in triplicate to quantify $\operatorname{luxAB}$ activity. A volume of $100 \mu \mathrm{l}$ of an $n$-decyl-aldehyde substrate solution $(0.2 \% n$-decyl-aldehyde [Sigma, St. Louis] in a $2.0 \%$ bovine serum albumin solution) was added. After thorough mixing, bioluminescence was determined using a luminescence counter (MicroBeta 1450 TriLux, Wallac, Turku, Finland). Luminescence was determined after approximately every 0.1 unit increase of $\mathrm{OD}_{620}$.

\section{Construction of mutants by homologous recombination.}

Disruption of the gacS homologous gene by homologous recombination was performed using pMP6016, a pIC20R-based Pseudomonas suicide plasmid containing a $0.3-\mathrm{kb}$ internal PCR fragment of the gacS-homologous gene of strain PCL1391 and a tetracycline resistance cassette. The PCR primers contained KpnI and EcoRI (underlined) restriction sites and annealed to nucleotide positions 1,084 to $1,103\left(5^{\prime}\right.$ CCGGAATTCGAGCCACGAAATCCGTACCC-3') and 1,294 to $1,313\left(5^{\prime}\right.$-CGGGGTACCTCAGGGTGTCCTGCAACAGG3'), having taken the adenine of the first ATG of the PCL1391 gacS gene as position one. Plasmid pMP6016 was transformed to strain PCL1391 Tn5luxAB derivatives by electroporation, and recombinants resulting from chromosomal integration were selected on $\mathrm{KB}$ agar medium supplemented with tetracycline $(160 \mu \mathrm{g} / \mathrm{ml})$ for PCL1391 or kanamycin $(50 \mu \mathrm{g} / \mathrm{ml})$ and tetracycline for Tn5-derivatives. Transformants were analyzed for proper recombination using Southern hybridization (Sambrook and Russell 2001). Double mutants were isolated by selection on medium with antibiotics for selecting both the initial Tn5 insertion and the newly introduced mutation. The second mutation introduced was confirmed using Southern hybridization.

A mutagenesis strategy similar to that described above was used for the introduction of mutations in psrA and nagZ. The psrA fragment for constructing the suicide plasmid pMP6015 for the introduction of a mutation in the psrA homologous gene was obtained by PCR, using primers oMP657 (5' CGGAATTCAACCGTTGAACGCATTCTC-3'), containing an EcoRI restriction site and annealing to positions 16 to 34, and oMP656 (5'-CGGAATTCAGGAACGGCACCATCAG-3'), con- taining a KpnI restriction site and annealing to positions 590 to 607 of the psrA gene of strain PCL1391.

The nagZ PCR fragment for construction of suicide plasmid pMP6049 was produced by using primers oMP646 (5'-GAA TTCGATCATCTTTGCCCGGAATA-3'), containing an EcoRI restriction site, and oMP647 (5'-GGGTACCGACGGTGTCA CTTTCAGAC-3'), containing a KpnI restriction site, annealed to positions 90 to 109 and 869 to 888 of the nagZ gene, respectively.

\section{Cloning of the $p s r A$ gene and promoter.}

The complete $p s r A$ gene and $199 \mathrm{bp}$ of the promoter region of psrA was amplified with PCR using primers oMP691 (5'GAATTCGCTTGGCAATCCTCCTTTTT-3') and oMP692 (5'-GAATTCATCGGCGAAAGATCTGAAAG-3'), both containing an EcoRI restriction site annealing to positions -199 to -179 and 779 to 798 relative to the start of the $p s r A$ gene, respectively. The 1.0-kb psrA fragment obtained was cloned into the EcoRI site of pBBR1MCS5, resulting in pMP6579. Plasmids were transformed to Pseudomonas using electroporation (1.25 kV/cm, $2.5 \mu \mathrm{F}, 200 \Omega$ ) (Gene Pulser, Bio-Rad Laboratories, Richmond, CA, U.S.A.).

\section{ACKNOWLEDGMENTS}

We thank P. Williams of the University of Nottingham for kindly providing the synthetic autoinducers and the reporter strain Chromobacterium violacea CV026. We thank A. La Rose for his help in part of the experiments. This project was partly supported by European Union-Biotechnology grants BI04-CT96.0181 and QLK3-CT-2000-31.759.

\section{LITERATURE CITED}

Ahmer, B. M. M., van-Reeuwijk, J., Watson, P. R., Wallis, T. S., and Heffron, F. 1999. Salmonella SirA is a global regulator of genes mediating enteropathogenesis. Mol. Microbiol. 31:971-982.

Appleby, J. L., Parkinson, J. S., and Bourret, R. B. 1996. Signal transduction via the multi-step phosphorelay: Not necessarily a road less traveled. Cell 86:845-848.

Bassler, B. L. 2002. Small talk. Cell-to-cell communication in bacteria. Cell 109:421-424.

Bauer, W. D., and Coplin, D. L. 2003. Quorum sensing in plant-pathogenic bacteria. Annu. Rev. Phytopathol. 41:455-482.

Bertani, I., Ševo, M., Kojic, M., and Venturi, V. 2003. Role of GacA, LasI, RhlI, Ppk, PsrA, Vfr and ClpXP in the regulation of the stationaryphase sigma factor rpoS/RpoS in Pseudomonas. Arch. Microbiol. 180:264-71.

van der Bij, A. J., de Weger, L. A., Tucker, W. T., and Lugtenberg, B. J. J. 1996. Plasmid stability in Pseudomonas fluorescens in the rhizosphere. Appl. Environ. Microbiol. 62:1076-1080.

Buell, C. R., Joardar, V., Lindeberg, M., Selengut, J., Paulsen, I. T., Gwinn, M. L., Dodson, R. J., Deboy, R. T., Durkin, A. S., Kolonay, J. F., Madupu, R., Daugherty, S., Brinkac, L., Beanan, M. J., Haft, D. H., Nelson, W. C., Davidsen, T., Zafar, N., Zhou, L., Liu, J., Yuan, Q., Khouri, H., Fedorova, N., Tran, B., Russell, D., Berry, K., Utterback, T., Van Aken, S. E., Feldblyum, T. V., D'scenzo, M., Deng, W. L., Ramos, A. R., Alfano, J. R., Cartinhour, S., Chatterjee, A. K., Delaney, T. P., Lazarowitz, S. G., Martin, G. B., Schneider, D. J., Tang, X., Bender, C. L., White, O., Fraser, C. M., Collmer, A. 2003. The complete genome sequence of the Arabidopsis and tomato pathogen Pseudomonas syringae pv. tomato DC3000. Proc. Natl. Acad. Sci. U.S.A. 100:10181-10186.

Boyer, H. W., and Roulland-Dussoix, D. 1969. A complementation analysis of the restriction and modification of DNA in Escherichia coli. J. Mol. Biol. 41:459-472.

Brent, R., and Ptashne, M. 1981. Mechanism of action of the lexA gene product. Proc. Natl. Acad. Sci. U.S.A. 78:4204-4208.

Calero, S., Garriga, X., and Barbe, J. 1993. Analysis of the DNA damagemediated induction of Pseudomonas putida and Pseudomonas aeruginosa lexA genes. FEMS (Fed. Eur. Microbiol. Soc.) Microbiol. Lett. 110:65-70.

Chancey, S. T., Wood, D. W., and Pierson, L. S. 1999. Two-component transcriptional regulation of $N$-acyl-homoserine lactone production in Pseudomonas aureofaciens. Appl. Environ. Microbiol. 65:2294-2299.

Chatterjee, A., Cui, Y., Liu, Y., Dumenyo, C. K., and Chatterjee, A. K. 
1995. Inactivation of rsmA leads to overproduction of extracellular pectinases, cellulases, and proteases in Erwinia carotovora subsp. carotovora in the absence of the starvation/cell density-sensing signal, $\mathrm{N}$-(3oxohexanoyl)-L-homoserine lactone. Appl. Environ. Microbiol. 61:1959-1967.

Chin-A-Woeng, T. F. C., Bloemberg, G. V., van der Bij, A. J., van der Drift, K. M. G. M., Schripsema, J., Kroon, B., Scheffer, R. J., Keel, C., Bakker, P. A. H. M., Tichy, H. V., de Bruijn, F. J., Thomas-Oates, J. E., and Lugtenberg, B. J. J. 1998. Biocontrol by phenazine-1-carboxamideproducing Pseudomonas chlororaphis PCL1391 of tomato root rot caused by Fusarium oxysporum f. sp. radicis-lycopersici. Mol. PlantMicrobe Interact. 11:1069-1077.

Chin-A-Woeng, T. F. C., Thomas-Oates, J. E., Lugtenberg, B. J. J., and Bloemberg, G. V. 2001a. Introduction of the phzH gene of Pseudomonas chlororaphis PCL1391 extends the range of biocontrol ability of phenazine-1-carboxylic acid-producing Pseudomonas spp. strains. Mol. Plant-Microbe Interact. 14:1006-1015.

Chin-A-Woeng, T. F. C., van den Broek, D., de Voer, G., van der Drift, K. M. G. M., Tuinman, S., Thomas-Oates, J. E., and Lugtenberg, B. J. J. 2001b. Phenazine-1-carboxamide production in the biocontrol strain Pseudomonas chlororaphis PCL1391 is regulated by multiple factors secreted into the growth medium. Mol. Plant-Microbe Interact. 14:969979

Chugani, S. A., Whiteley, M., Lee, K. M., D'rgenio, D., Manoil, C., and Greenberg, E. P. 2001. QscR, a modulator of quorum-sensing signal synthesis and virulence in Pseudomonas aeruginosa. Proc. Natl. Acad. Sci. U.S.A 98:2752-2757.

Cui, Y., Chatterjee, A., Liu, Y., Dumenyo, C. K., and Chatterjee, A. K. 1995. Identification of a global repressor gene, rsmA, of Erwinia carotovora subsp. carotovora that controls extracellular enzymes, N-(3-oxohexanoyl)-L-homoserine lactone, and pathogenicity in soft-rotting $\mathrm{Er}$ winia spp. J. Bacteriol. 177:5108-5115.

de Souza, J. T., Mazzola, M., and Raaijmakers, J. M. 2003. Conservation of the response regulator gene gacA in Pseudomonas species. Environ. Microbiol. 5:1328-1340.

Diggle, S. P., Winzer, K., Lazdunski, A., Williams, P., and Camara, M. 2002. Advancing the quorum in Pseudomonas aeruginosa: MvaT and the regulation of $\mathrm{N}$-acylhomoserine lactone production and virulence gene expression. J. Bacteriol. 184:2576-2586.

Garriga, X., Calero, S., and Barbe, J. 1992. Nucleotide sequence analysis and comparison of the lexA genes from Salmonella typhimurium, Erwinia carotovora, Pseudomonas aeruginosa and Pseudomonas putida. Mol. Gen. Genet. 236:125-134.

Geels, F. P., and Schippers, G. 1983. Selection of antagonistic fluorescent Pseudomonas spp. and their root colonization and persistence following treatment of seed potatoes. Phytopath Z. 108:193-206.

Hanahan, D. 1983. Studies on transformation of Escherichia coli with plasmids. J. Mol. Biol. 166:557-580.

Hanzelka, B. L., and Greenberg, E. P. 1996. Quorum sensing in Vibrio fischeri: Evidence that $S$-adenosylmethionine is the amino acid substrate for autoinducer synthesis. J. Bacteriol. 178:5291-5294.

Heeb, S., and Haas, D. 2001. Regulatory roles of the GacS/GacA twocomponent system in plant-associated and other gram-negative bacteria. Mol. Plant-Microbe Interact. 14:1351-1363.

Heeb, S., Itoh, Y., Nishijyo, T., Schnider, U., Keel, C., Wade, J., Walsh, U., O'Gara, F., and Haas, D. 2000. Small, stable shuttle vectors based on the minimal pVS1 replicon for use in gram-negative, plant-associated bacteria. Mol. Plant-Microbe Interact. 13:232-237.

Hrabak, E. M., and Willis, D. K. 1992. The lemA gene required for pathogenicity of Pseudomonas syringae pv. syringae. J. Bacteriol. 174:30113020

Jarvis, W. R., and Shoemaker, R. A., 1978 Taxonomic status of Fusarium oxysporum causing foot and root rot of tomato. Phytopathology 68:1679-1680

King, E. O., Ward, M. K., and Raney, D. E. 1954. Two simple media for the demonstration of pyocyanin and fluorescein. J. Lab. Clin. Med. 44:301-307.

Kojic, M., and Venturi, V. 2001. Regulation of rpoS gene expression in Pseudomonas: Involvement of a TetR family regulator. J. Bacteriol. 183:3712-3720.

Kojic, M., Aguilar, C., and Venturi, V. 2002. TetR family member psrA directly binds the Pseudomonas rpoS and psrA promoters. J. Bacteriol. 184:2324-2330.

Kovach, M. E., Elzer, P. H., Hill, D. S., Robertson, G. T., Farris, M. A., Roop, R. M., and Peterson, K. M. 1995. Four new derivatives of the broad-host-range cloning vector pBBR1MCS, carrying different antibiotic-resistance cassettes. Gene 166:175-176.

Latifi, A., Winson, M. K., Foglino, M., Bycroft, B. W., Stewart, G. S. A. B., Lazdunski, A., and Williams, P. 1995. Multiple homologues of LuxR and LuxI control expression of virulence determinants and secon- dary metabolites through quorum sensing in Pseudomonas aeruginosa PAO1. Mol. Microbiol. 17:333-343.

Laville, J., Voisard, C., Keel, C., Maurhofer, M., Défago, G., and Haas, D. 1992. Global control in Pseudomonas fluorescens mediating antibiotic synthesis and suppression of black root rot of tobacco. Proc. Natl. Acad. Sci. U.S.A. 89:1562-1566.

Little, J. W., Mount, D. W., and Yanisch, P. C. 1981. Purified lexA protein is a repressor of the recA and lexA genes. Proc. Natl. Acad. Sci. U.S.A. 78:4199-4203.

Loh, J., Pierson, E. A., Pierson, L. S., Stacey, G., and Chatterjee, A. 2002. Quorum sensing in plant-associated bacteria. Curr. Opin. Plant Biol. 5:285-290.

Mahajan, M. S., Tan, M. W., Rahme, L. G., and Ausubel, F. M. 1999. Molecular mechanisms of bacterial virulence elucidated using a Pseudomonas aeruginosa-Caenorhabditis elegans pathogenesis model. Cell 96:47-56

Marsh, J. L., Erfle, M., and Wykes, E. J. 1984. The pIC20 plasmid and phage vectors with versatile cloning sites for recombinant selection by insertional inactivation. Gene 32:481-485.

Mavrodi, D. V., Ksenzenko, V. N., Chatuev, B. M., Thomashow, L. S., and Boronin, A. M. 1997. Structural and functional organization of Pseudomonas fluorescens genes encoding enzymes of phenazine-1-carboxylic acid biosynthesis. Mol. Biol. 31:62-68.

McClean, K. H., Winson, M. K., Fish, L., Taylor, A., Chhabra, S. R., Camara, M., Daykin, M., Lamb, J. H., Swift, S., Bycroft, B. W., Stewart, G. B., and Williams, P. 1997. Quorum sensing and Chromobacterium violaceum: Exploitation of violacein production and inhibition for the detection of $N$-acylhomoserine lactones. Microbiology 143:3703-3711.

Nelson, K. E., Weinel, C., Paulsen, I. T., Dodson, R. J., Hilbert, H., Martins dos Santos, V. A. P., Fouts, D. E., Gill, S. R., Pop, M., Holmes, M., Brinkac, L., Beanan, M., DeBoy, R. T., Daugherty, S., Kolonay, J., Madupu, R., Nelson, W., White, O., Peterson, J., Khouri, H., Hance, I., Chris Lee, P., Holtzapple, E., Scanlan, D., Tran, K., Moazzez, A., Utterback, T., Rizzo, M., Lee, K., Kosack, D., Moestl, D., Wedler, H., Lauber, J., Stjepandic, D., Hoheisel, J., Straetz, M., Heim, S., Kiewitz, C., Eisen, J. A., Timmis, K. N., Dusterhoft, A., Tummler, B., and Fraser, C. M. 2002. Complete genome sequence and comparative analysis of the metabolically versatile Pseudomonas putida KT2440. Environ. Microbiol. 4:799-808.

Newton, J. A., and Fray, R. G. 2004. Integration of environmental and host-derived signals with quorum sensing during plant-microbe interactions. Cell Microbiol. 6:213-24.

Pernestig, A. K., Melefors, O., and Georgellis, D. 2001. Identification of UvrY as the cognate response regulator for the BarA sensor kinase in Escherichia coli. J. Biol. Chem. 276:225-231.

Pessi, G., Williams, F., Hindle, Z., Heurlier, K., Holden, M. T., Camara, M., Haas, D., and Williams, P. 2001. The global posttranscriptional regulator RsmA modulates production of virulence determinants and $\mathrm{N}$ acylhomoserine lactones in Pseudomonas aeruginosa. J. Bacteriol. 183:6676-6683.

Reimmann, C., Beyeler, M., Latifi, A., Winteler, H., Foglino, M., Lazdunski, A., and Haas, D. 1997. The global activator GacA of Pseudomonas aeruginosa PAO positively controls the production of the autoinducer $\mathrm{N}$-butyryl-homoserine lactone and the formation of the virulence factors pyocyanin, cyanide, and lipase. Mol. Microbiol. 24:309-319.

Rice, P., Longden, I., and Bleasby, A. 2000. EMBOSS: The European molecular biology open software suite. Trends Genet. 16:276-277.

Rich, J. J., Kinscherf, T. G., Kitten, T., and Willis, D. K. 1994. Genetic evidence that the gacA gene encodes the cognate response regulator for the lemA sensor in Pseudomonas syringae. J. Bacteriol. 176:74687475

Sacherer, P., Défago, G., and Haas, D. 1994. Extracellular protease and phospholipase $\mathrm{C}$ are controlled by the global regulatory gene gacA in the biocontrol strain Pseudomonas fluorescens CHA0. FEMS Microbiol. Lett. 116:155-160.

Salmond, G. P. C., Bycroft, B. W., Stewart, G. S. A. B., and Williams, P. 1995. The bacterial 'enigma': Cracking the code of cell-cell communication. Mol. Microbiol. 16:615-624.

Sambrook, J., and Russel, D. W. 2001. Molecular Cloning: A Laboratory Manual. Cold Spring Harbor Laboratory Press, Cold Spring Harbor, NY, U.S.A.

Sarniguet, A., Kraus, J., Henkels, M. D., Muehlchen, A. M., and Loper, J. E. 1995. The sigma factor $\sigma^{\mathrm{s}}$ affects antibiotic production and biological activity of Pseudomonas fluorescens PF5. Proc. Natl. Acad. Sci. U.S.A. 92:12255-12259.

Simons, M., van der Bij, A. J., Brand, J., de Weger, L. A., Wijffelman, C. A., and Lugtenberg, B. J. J. 1996. Gnotobiotic system for studying rhizosphere colonization by plant growth-promoting Pseudomonas bacteria. Mol. Plant-Microbe Interact. 9:600-607.

Sonnleitner, E., Hagens, S., Rosenau, F., Wilhelm, S., Habel, A., Jager, K. 
and Blasi, U. 2003. Reduced virulence of a $h f q$ mutant of Pseudomonas aeruginosa O1. Microb. Pathogenesis 35:217-228.

Stover, C. K., Pham, X. Q., Erwin, A. L., Mizoguchi, S. D., Warrener, P., Hickey, M. J., Brinkman, F. S., Hufnagle, W. O., Kowalik, D. J., Lagrou, M., Garber, R. L., Goltry, L., Tolentino, E., Westbrock-Wadman, S., Yuan, Y., Brody, L. L., Coulter, S. N., Folger, K. R., Kas, A., Larbig, K., Lim, R., Smith, K., Spencer, D., Wong, G. K., Wu, Z., and Paulsen, I. T. 2000. Complete genome sequence of Pseudomonas aeruginosa PA01, an opportunistic pathogen. Nature 406:959-964.

Suh, S. J., Silo-Suh, L., Woods, D. E., Hassett, D. J., West, S. E., and Ohman, D. E. 1999. Effect of rpoS mutation on the stress response and expression of virulence factors in Pseudomonas aeruginosa. J. Bacteriol. 181:3890-3897.

Swift, S., Downie, J. A., Whitehead, N. A., Barnard, A. M., Salmond, G. P., and Williams, P. 2001. Quorum sensing as a population-densitydependent determinant of bacterial physiology. Adv. Microb. Physiol. 45:199-270.

Throup, J. P., Camara, M., Briggs, G. S., Winson, M. K., Chhabra, S. R., Bycroft, B. W., Williams, P., and Stewart, G. S. A. B. 1995. Characterisation of the yenI/yenR locus from Yersinia enterocolitica mediating the synthesis of two $N$-acylhomoserine lactone signal molecules. Mol. Microbiol. 17:345-356.

Turner, J. M., and Messenger, A. J. 1986. Occurrence, biochemistry and physiology of phenazine pigment production. Adv. Microb. Physiol. 27:211-275

Venturi, V. 2003. Control of rpoS transcription in Escherichia coli and Pseudomonas: Why so different? Mol. Microbiol. 49:1-9.
Von Bodman, S. B., Bauer, W. D., and Coplin, D. L. 2003. Quorum sensing in plant-pathogenic bacteria. Annu. Rev. Phytopathol. 41:455-82.

Whistler, C. A., and Pierson, L. S. 2003. Repression of phenazine antibiotic production in Pseudomonas aureofaciens strain $30-84$ by RpeA. J. Bacteriol. 185:3718-3725.

Whistler, C. A., Corbell, N. A., Sarniguet, A., Ream, W., and Loper, J. E. 1998. The two-component regulators GacS and GacA influence accumulation of the stationary-phase sigma factor sigma $\sigma^{\mathrm{S}}$ and the stress response in Pseudomonas fluorescens Pf-5. J. Bacteriol. 180:6635-6641.

Winzer, K., Hardie, K. R., and Williams, P. 2002. Bacterial cell-to-cell communication: Sorry, can't talk now-Gone to lunch! Curr. Opin. Microbiol. 5:216-222.

Wolk, C. P., Cai, Y., and Panoff, J. M. 1991. Use of a transposon with luciferase as a reporter to identify environmentally responsive genes in a cyanobacterium. Proc. Natl. Acad. Sci. U.S.A. 88:5355-5359.

Wood, D. W., Gong, F. C., Daykin, M. M., Williams, P., and Pierson, L. S. 1997. $N$-acyl-homoserine lactone-mediated regulation of phenazine gene expression by Pseudomonas aureofaciens 30-84 in the wheat rhizosphere. J. Bacteriol. 179:7663-7670.

Zhang, Z., and Pierson, L. S. 2001. A second quorum sensing system regulates cell surface properties but not phenazine antibiotic production in Pseudomonas aureofaciens. Appl. Environ. Microbiol. 67:43054315.

Zhu, J., and Winans, S. C. 1999. Autoinducer binding by the quorum-sensing regulator TraR increases affinity for target promoters in vitro and decreases TraR turnover rates in whole cells. Proc. Natl. Acad. Sci. U.S.A 96:4832-4837. 